\title{
Impact of Food and Fuel Prices on Poverty in Oil Exporting Economies: The Case of Sultanate of Oman
}

\author{
H.B. Kotagama and H. Boughanmi ${ }^{1}$
}

\begin{abstract}
The drastic drop in fuel prices and the resulting fiscal constraints have compelled oil exporting countries to phase down fuel subsidies. The government of Oman raised gas prices for industrial users by 100\% in 2015 with 3\% annual increase, and in early 2016 increased oil fuel prices by 33\% with possibility of monthly adjustments, in future. The increase in the fuel prices resulted to an increase in domestic food prices too. The phasing down of fuel subsidies would influence poverty and household food security in Oman. In this context, the objective of the study is to quantitatively analyze the impact and sensitivity of food and fuel price changes on incidence of poverty in Oman. This study uses a simulation model developed by the World Bank that estimates the impact of increase in food and fuel prices on poverty incidence and the required fiscal allocation to neutralize the poverty incidence. The results indicate that poverty incidence is responsive to fuel price changes in Oman. It is estimated that increase of fuel prices by $33 \%$ increases poverty incidence by $1 \%$ from current baseline of $12.78 \%$. The financial transfer that is required to neutralize poverty incidence due to increase of fuel prices by $33 \%$ is substantially lower than the savings made by phasing down fuel subsidies. The government could use the existing mechanism and institutions of social security provisions to target and provide financial transfers to poor household that would be adversely affected by phasing down of fuel subsidies.
\end{abstract}

Keywords: Fuel subsidies, Food security, Social safety, Simulation modelling.

1 Assistant Professor and Associate Professor, respectively at the Department of Natural Resource Economics, College of Agricultural and Marine Sciences, Sultan Qaboos University, Sultanate of Oman. 


\section{Introduction}

The surge and volatility of food and fuel prices from year 2008 to 2014 has changed its trend to decreasing food and fuel prices since 2015. However the rate of decrease in food prices has been less than the rate of decrease in fuel prices (figure 1). Predictions (World Bank, 2016) are that fuel prices may not revert back to high prices that prevailed in 2013 (104.1 \$/barrel) even by 2025 (82.6 \$/barrel). This scenario of relatively high food prices to low fuel prices, would adversely impact poverty and food security in countries that are highly food import and oil export dependent, such as the Sultanate of Oman.

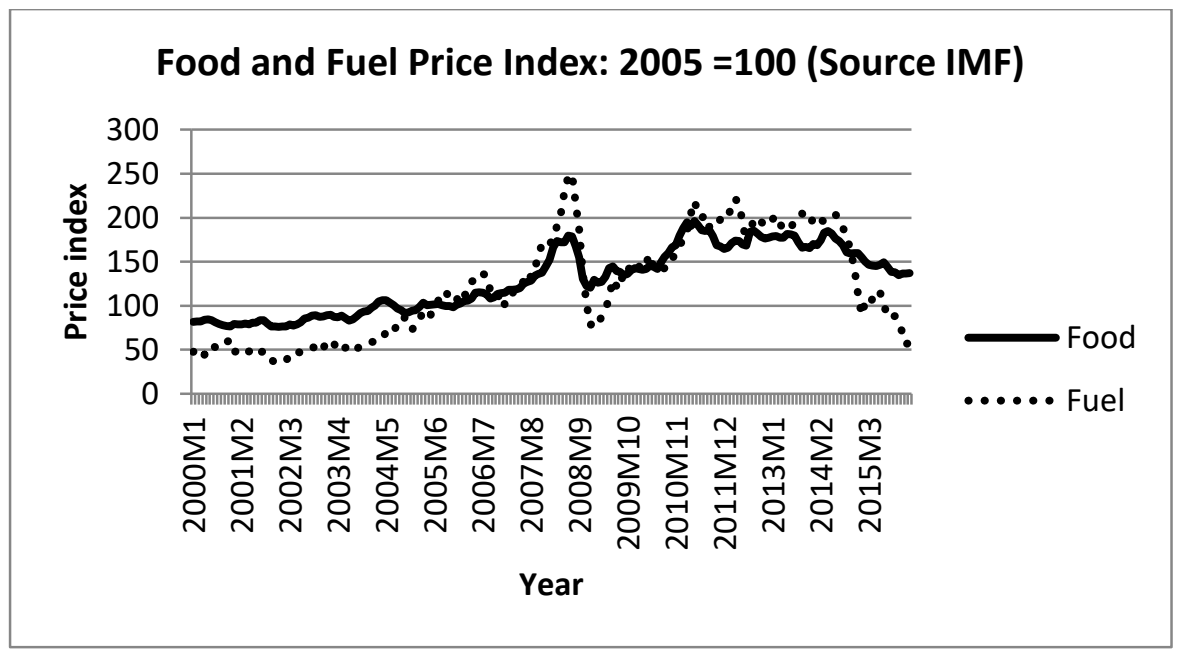

Figure1. Food and fuel price changes over time

In the Sultanate of Oman, non-renewable resource based fuels and mineral products exports constitute a major part of the trade balance, accounting for $83 \%$ of total exports. Food imports represent $12.4 \%$ of total imports values. The trade balance of the Sultanate of Oman though was in surplus up to 2014, with the decrease in the oil price it has been in deficit since 2015 (World Bank, 2016). The government of the Sultanate of Oman, through its budgetary proposals for 2016 has initiated reforms to augment government revenue, through increases in business taxes and phasing down subsidies on fuel. Further policy initiatives and economic reforms are being considered (Pricewaterhouse Coopers International Limited, 2016). Of total government subsidy of 1.98 billion, OR 1.4 billion OR is for support of petroleum products and electricity sector in 2014 (Central Bank of Oman, 2014) of which 1.1 billion OR (about 55\% of total subsidies) was for oil subsidy (International Energy Agency, 2015). The government of Oman raised gas prices for industrial users of gas by $100 \%$ in 2015 with $3 \%$ annual increase (International Energy Agency, 2015). In 2016 the government 
of Oman increased oil fuel prices by $33 \%$ with possibility of monthly adjustments in future.

Oman imported $44 \%$ of the food consumed, $100 \%$ of rice and about $95 \%$ of wheat (Kotagama et al., 2014). Expenditure on food is the largest percentage $(32.8 \%)$ of the total household income followed by transportation (14.2\%) that is largely cost on fuel (National Centre for Statistics Information, 2012). Thus changes in either, food or fuel prices, would have a significant impact on household welfare and poverty. In Sultanate of Oman, a family is classified as poor if it spends more than $60 \%$ of the household expenditure on food (Ministry of National Economy, 2010). Based on this standard $12 \%$ of Omani families were classified as poor based on Household Expenditure and Income Survey conducted in 2007-2008 compared to 8\% in 1999-2000 (Al Jabri, 2011). Studies, done post 2008 surge in global food prices, have quantified the resulting increase in food insecurity in the Sultanate of Oman, measured as percentage of households unable to access Nutrionally Adequate Socially Preferred Least Cost diet as 5.3\% (Kotagama et al., 2014). The phasing down of fuel subsidies may further aggravate poverty and household food security. In this context the specific objective of the study was to conduct a quantitative analysis on the impact and sensitivity of food and fuel price changes on incidence of poverty to address the objective of assessing policy options to mitigate poverty and manage public finances.

\section{Literature Review}

Fuel subsidies are justified to support poor households and once provided changes of the fuel subsidy is a politically sensitive issue. Phasing down fuel subsidies has been justified as subsidies result to: distorting markets and thus causes inefficient resource allocation, discouraging energy efficient innovations, negative environmental impacts, inequitable income distribution, fiscal constraints and crowding out public expenditure that can be used for social infrastructure and poverty alleviating investments. Most empirical studies have examined the impact of fuel subsidies on fiscal and income distribution aspects. Dartanto (2013), by using a computable general equilibrium model on Indonesian economy have reported that almost $72 \%$ of the fuel subsidy was enjoyed by the richest $30 \%$ of the population and that removing $25 \%$ of the fuel subsidy would increase the incidence of poverty by $0.26 \%$. Further, the allocation of saved finances from the subsidy reduction could bring down poverty by $0.27 \%$. Anand et al. (2013) have reported that inappropriately targeted fuel subsidies in India has enabled the richest $10 \%$ to receive 7 times 
more in benefit than the poorest $10 \%$ of the population. It has been estimated that eliminating fuel subsidy in India would result to $4 \%$ decrease in real household income. About $75 \%$ of this impact on household welfare is due to the direct impact of the fuel price change on use of fuel. Siddig et al. (2014), using general equilibrium model associated with GTAP modeling framework for Nigeria, have found that in general, reduction of fuel subsidy would increase the Nigerian GDP, whilst would have detrimental impact on income of particularly the poor households. Using a simulation model that estimates only the direct effects of fuel price change on poverty in Nigeria, Rentscler (2015) have found that the direct effects of increased kerosene fuel will adversely impact the poorest households. It is estimated that a $100 \%$ reduction of subsidies would increase poverty head count rate by about 3.3\%. Coady et al. (2015) have reviewed studies done in 32 countries to estimate the welfare impact of increasing fuel prices. The review confirms that a larger share of fuels subsidies is accrued to high income households. In the middle-eastern countries the pass-through of international fuel prices to domestic prices was estimated to about $13 \%$ and as a consequence the fiscal cost of the subsidy has exceeded 3\% of GDP. They have estimated that a $0.25 \$ /$ liter increase in fuel prices would result in $5.5 \%$ decline in household real income on the average and about 7\% in Middle Eastern countries. On average the indirect impact of a change in fuel price on household welfare was $55 \%$. Further it has been estimated that the richest $20 \%$ receives 6 times more benefits of the fuel subsidy than the poorest $20 \%$ in society.

\section{Methodology}

The poverty incidence of households would be impacted by increases in fuel price (decrease in subsidy) directly through changes on quantity of fuel consumed by the household and indirectly through changes in prices of other non-fuel commodities that uses fuel and is consumed by households. The impact of a fuel price change, on overall poverty incidence of society will primarily depend on income distribution and differences in the quantities of fuel consumption and non-fuel commodities consumed by households' with different levels of income. This study has used a simulation model that estimates the poverty impacts caused by changes in food and fuel prices developed by the World Bank (Kshirsagar et.al., 2009). The model enables the estimation of poverty head count and poverty depth indicators and the required governmental financial transfers to mitigate poverty (neutralize poverty) caused by changes in food and fuel prices. This study estimates the poverty head count as the number of households under poverty over 
the population as a percentage. A technical detailed explanation of the model is provided by Kshirsagar et.al. (2009).

In brief, the model disaggregates the economy into three sectors: Agriculture, industry and services. Changes in commodity prices (food and fuel) will affect the sectoral and the general inflation (Consumer Price Index (CPI)), the sectoral growth rates, individual consumption, and the real poverty line. Two measures of inflation, the consumer price inflation $\inf f_{c p i}$ and the poverty basket inflation $\inf f_{\text {pov }}$ are calculated as in equation 1 .

$$
\begin{aligned}
& \text { inf } f_{c p i}=\sum_{i} \inf _{i} w_{i}^{c p i} \quad \text { inf } f_{\text {pov }}=\sum_{i} i n f_{i} w_{i}^{\text {pov }} \quad i \in \\
& \text { \{food,fuel, other\} } \\
& \text {... Eq. } 1
\end{aligned}
$$

Where $w_{i}^{c p i}$ and $w_{i}^{p o v}$ are CPI weights and poverty basket weights. Since the poorer consumes relatively consume more cereals and less meat and fuels than the non-poorer, these weights will be different. The model allows the changes in fuel prices to have a direct and indirect impact on household welfare via the non-food non energy (NFNE) inflation which is assumed to depend on fuel prices via the equation 2.

$$
\text { infl } l_{n f n e}=\inf f_{n f n e}^{\text {direct }}+P T_{n f n e}^{\text {fuel }} * i n f_{\text {fuel }} \quad \ldots \text { Eq. } 2
$$

Where $P T_{n f n e}^{f u e l}$ is the pass through of changes in fuel prices into non-food-non energy prices. The model simulates the impact of higher commodity prices on household by simulating the expected changes in consumption and poverty line as equation 3 .

$$
c_{i j}(t+1)=c_{i j}(t)\left[1+\Delta G D P_{p c_{i}}\right]+\Delta c t * I_{c t} \quad \ldots \text { Eq. } 3
$$

Where $c_{i j}$ is consumption by individual $i$ in sector $j, \Delta G D P_{p c_{i}}$ is the change in GDP per capita in sector $i, \Delta c t$ is the change in cash transfers, and $I_{c t}$ is a dummy indicating whether the household receives cash transfers. The change in the sectoral GDP is adjusted by a passthrough parameter measuring the extent to which changes in sectoral GDP translates into household consumption. Increases in commodity prices (PL) will increase the cost of the poverty basket and therefore affect the poverty line will be as shown by equation 4:

$$
P L(1+t)=P L(t)\left[1+i n f_{p o v}\right] \quad \quad \ldots \text { Eq. } 4
$$

A household $j$ in sector $i$ is considered poorer if $C_{i j}(t+1)<$ $P L(t+1)$. The national poverty incidence is obtained by summing over all poorer households adjusted by the population weights for each of 
these households (see Kshirsagar et.al, 2009 for further details). Given below is a schematic presentations of the model flow diagram (figure 2) and the data requirement and description of model output (table 1) adopted from Simler (2010).

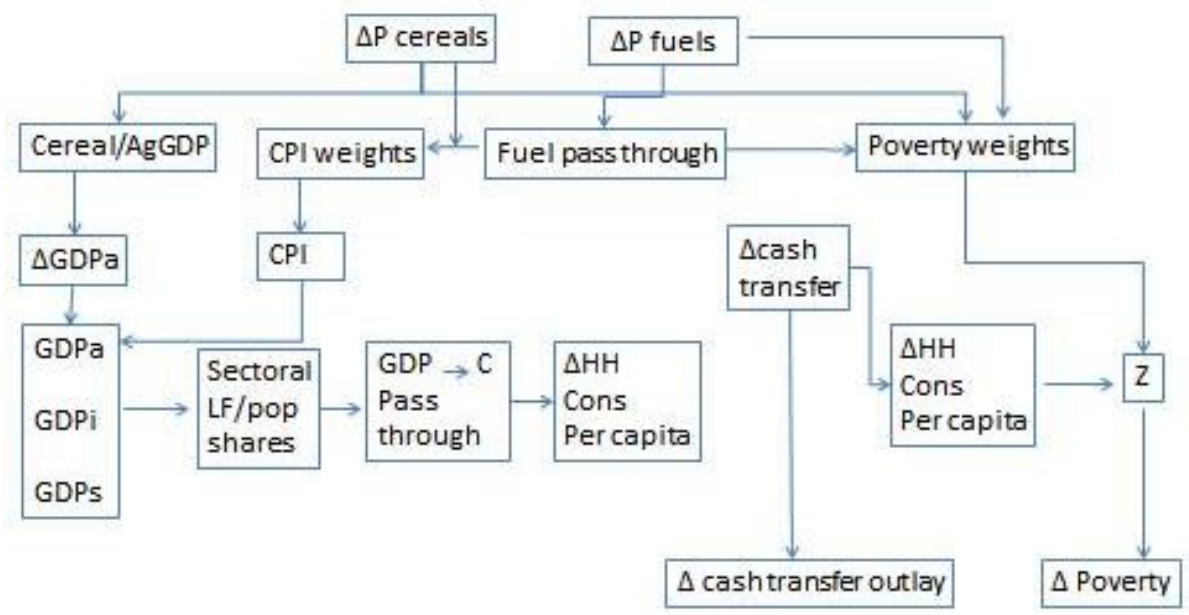

Source: Adopted from Simler (2010)

\section{Figure 2. Flow diagram of the model}

Table 1. Data requirements, choice variables and the outputs of the model

\begin{tabular}{lll}
\hline Data requirements & Choice variable & $\begin{array}{l}\text { Output (before and } \\
\text { after scenarios) }\end{array}$ \\
\hline Forecasts for GDP by sector & $\begin{array}{l}\text { Change in food } \\
\text { and fuel prices }\end{array}$ & $\begin{array}{l}\text { Poverty headcount \& } \\
\text { poverty gap by sector }\end{array}$ \\
\hline $\begin{array}{l}\text { Net cereal production share } \\
\text { of agricultural GDP }\end{array}$ & $\begin{array}{l}\text { Changes in cash } \\
\text { transfer benefit }\end{array}$ & $\begin{array}{l}\text { Real GDP growth by } \\
\text { sector }\end{array}$ \\
\hline Employment shares by sector & $\begin{array}{l}\text { Inflation (food, fuel, } \\
\text { NFNF, total) }\end{array}$ \\
\hline $\begin{array}{l}\text { Inflation forecasts (overall \& } \\
\text { commodities of interest }\end{array}$ & $\begin{array}{l}\text { Total outlay for cash } \\
\text { transfer }\end{array}$ \\
\hline Weights for CPI basket & \\
\hline Population (projections) & \\
\hline $\begin{array}{l}\text { Consumption/ income vector } \\
\text { from household survey }\end{array}$ & \\
\hline $\begin{array}{l}\text { Household's sector of } \\
\text { employment }\end{array}$ & \\
\hline Amount of cash transfer \\
received
\end{tabular}

Secondary macroeconomic data and simulated data using the most recent Household Expenditure and Income Survey of the Sultanate 
of Oman have been used for the study. The income distribution of Oman upon which the analysis mainly depends is given in table 2. Kotagama et.al. (2014) upon analysis of food insecurity (as proxy of poverty) caused by increased food prices in 2008 have shown that in Oman the improvement of income distribution has cushioned the impact on food insecurity caused by increase in food prices more than the increase in household income. The average income of an Omani household is 1024 $\mathrm{OR} /$ month. Based on income distribution (table 2) and household size (table 3) a 9000 household sample was simulated for this analysis. Oman's population by 2015 was 4.155 million with a growth rate of 0.4 per cent. Omani citizens' population was 2,325,982, while the expatriates numbered $1,892,143$. The study is based only on Omani citizens' population.

Table 2. Income distribution in Oman in 2011

\begin{tabular}{ll}
\hline Income (OR/Month/Household) & $\%$ of population \\
\hline Less than 100 & 0.5 \\
$100-199$ & 2.2 \\
$200-299$ & 4.9 \\
$300-399$ & 6.8 \\
$400-499$ & 7.6 \\
$500-599$ & 7.4 \\
$600-699$ & 7.8 \\
700 and more & 62.9 \\
\hline
\end{tabular}

Source: NCSI (2012)

Table 3. Household size and monthly household income

\begin{tabular}{llll}
\hline $\begin{array}{l}\text { Average household } \\
\text { size (persons) }\end{array}$ & $\begin{array}{l}\text { \% of total } \\
\text { households }\end{array}$ & $\begin{array}{l}\text { \% share in total } \\
\text { household income }\end{array}$ & $\begin{array}{l}\text { Average per } \\
\text { capita income } \\
\text { (OR) }\end{array}$ \\
\hline $1-3$ & 32.9 & 5.5 & 231.8 \\
$4-6$ & 27.7 & 19.9 & 182.3 \\
$7-9$ & 19.7 & 29.6 & 142.2 \\
$10-12$ & 11.8 & 22.5 & 125.9 \\
$13+$ & 7.9 & 22.5 & 130.0 \\
\hline Total & 100 & 100 & 812.2 \\
\hline Soul
\end{tabular}

Source: NCSI (2012)

An Oman family is classified as poor if it spends more than $60 \%$ of the household expenditure on food (MNE, 2010). Accordingly the poverty line is approximately $300 \mathrm{OR} / \mathrm{month} /$ household and with a household size of 8.5 members the per capita poverty lines is about 35 OR/month (Mbaga and Kotagama, 2010). The base macro-economic data for Oman (CBO, 2014) that was used in the model is given in table 4. The predictions on population and GDP were based on national 
statistics. The food basket for an average household and of family below poverty is given in table 5 (Mbaga and Kotagama, 2010).

Table 4. Macroeconomic data

\begin{tabular}{ll}
\hline Variable & Value (OR million) \\
\hline Real GDP (constant LCU: OR Million) & \\
Agriculture & 406.1 \\
Industry & 20,546 \\
Services & $12,814.5$ \\
Employment Share & \\
Agriculture & 0.050 \\
Industry & 0.400 \\
Services & 0.550 \\
Real GDP pc (constant LCU: OR) & \\
Agriculture & $3,491.9$ \\
Industry & $22,083.1$ \\
Services & $10,016.9$ \\
Net Cereal Production/ Agricultural GDP & 0.01 \\
Population & $2,325,982$ \\
\hline Source Centrat Bank &
\end{tabular}

Source: Central Bank of Oman (2014)

Table 5. Household expenditure data

\begin{tabular}{lll}
\hline $\begin{array}{l}\text { Expenditure } \\
\text { component }\end{array}$ & $\begin{array}{l}\text { Share of expenditure } \\
\text { component in households } \\
\text { above poverty }\end{array}$ & $\begin{array}{l}\text { Share of expenditure } \\
\text { component in households } \\
\text { under poverty }\end{array}$ \\
\hline Maize & 0.036 & 0.072 \\
Wheat & 0.015 & 0.031 \\
Rice & 0.070 & 0.139 \\
Other Cereals & 0.003 & 0.006 \\
Other Food & 0.208 & 0.416 \\
Fuel & 0.144 & 0.095 \\
Non-Food & 0.524 & 0.241 \\
Non-Fuel & & \\
\hline
\end{tabular}

Source: Mbaga and Kotagama (2010).

Oman has a social security system which provides a monthly salary and other concessions on government services for families that do not have a regular monthly income. The monthly salary provided per family ranges from 80 to 264 OR. In 201584,644 families have been supported with disbursement of 27.87 million OR (MSD, 2015).

\section{Results and Discussion}

The simulated base scenario validated the model as the estimate of poverty incidence (\% households under poverty) was congruent with the national estimates (table 6). The model estimated that poverty 
incidence at present as $12.8 \%$ and the transfer of finance required to bring down poverty incidence to $0 \%$ (poverty neutral) as about 500 $\mathrm{OR} /$ Year/Household and the required total financial transfer as $20.4 \mathrm{OR}$ million. According to national statistics, the transfer of finance as food subsidy has been 19.3 OR million in 2014. The simulation on the recent (2016) post fuel price increase, which was an increase of $33 \%$ of fuel price, indicated that poverty incidence has increased by about $1 \%$ from the base level (table 6).

Table 6. Poverty impact due to the recent $33 \%$ increase in fuel prices

\begin{tabular}{lll}
\hline & Baseline & Simulation \\
\hline Poverty Incidence (\%) & & \\
Agriculture & 1.23 & 1.65 \\
Industry & 9.76 & 10.58 \\
Services & 14.25 & 15.23 \\
\hline Total & 12.78 & 13.73 \\
\hline
\end{tabular}

The incremental cost to compensate households that fall below the poverty line due to the recent increase in fuel prices is estimated at about 0.82 million compared to the cost saving to the government of 162 Million OR on phasing down oil subsidy (increase of fuel price by $33 \%$ ). Currently world food prices are on a declining trend. However if food prices are also increased by $30 \%$ with an increase of $33 \%$ fuel price increase the poverty incidence would increase by about $3 \%$ (table 7 ).

Table 7. Poverty impact due to the recent $33 \%$ increase in fuel prices and $30 \%$ increase in staple food

\begin{tabular}{lll} 
& Baseline & Simulation \\
\hline Poverty Incidence (\%) & & \\
Agriculture & 1.23 & 1.65 \\
Industry & 9.76 & 11.70 \\
Services & 14.25 & 16.76 \\
\hline Total & 12.78 & 15.06 \\
\hline
\end{tabular}

Simulation of increasing Oman's petroleum price of 0.120 OR/Liter to international petroleum price of 0.414 OR/Liter $(344 \%$ increase) indicates that poverty incidence would increase to $26.0 \%$ from the base of $12.8 \%$ (table 8). Yet the incremental transfer required (12.3 Million OR) to bring poverty to the base line is substantially less than cost savings of reducing the subsidy (by increasing the petroleum prices by $33 \%$ the cost savings is 162 million OR). 
Table 8. Poverty impact of increasing fuel prices to world average price

\begin{tabular}{lll}
\hline & Baseline & Simulation \\
\hline Poverty Incidence $(\%)$ & & \\
Agriculture & 1.24 & 3.10 \\
Industry & 9.76 & 23.19 \\
Services & 14.26 & 28.05 \\
\hline Total & 12.79 & 26.10 \\
\hline
\end{tabular}

The results indicate that poverty incidence is responsive to food and fuel price changes in Oman. The financial transfer that is required to compensate households that fall under poverty is substantially lower than the savings made by phasing down fuel subsidies. The government could use the existing mechanism institutions of social security provisions to target and provide financial transfers to the poor household that would be adversely affected by phasing down of fuel subsidies.

\section{Conclusions}

The study indicates that poverty incidence is responsive to food and fuel price changes in Oman. The financial transfer that is required to compensate households that fall under poverty is substantially lower than the savings made by phasing down fuel subsidies. The government could use the existing mechanism institutions of social security provisions to target and provide financial transfers to the poor household that would be adversely affected by phasing down of fuel subsidies.

\section{Acknowledgement}

This study was conducted on the financial sponsorship and facilitation of the World Trade Organization Chair program at the Department of Natural Resource Economics, College of Agricultural and Marine Sciences, Sultan Qaboos University. The authors acknowledge the contribution in data collection of two research assistants, H. Al-Farsi and N Al- Hamedi.

\section{References}

Al Jabri, S. (2011). Economic Analysis of Household Food Security in the Sultanate of Oman, Unpublished MSc Thesis, College of Agricultural and Marine Sciences, Sultan Qaboos University, Oman.

Anand, R., Mahommad, C.D., Thakoor, A., and Walsh, J. (2013). The Fiscal and Welfare Impacts of Reforming Fuel Subsidies in 
India, IMF working paper WP/13/128, International Monetary Fund.

Central Bank of Oman (2014). Annual Report 2014.

Coady, D., Flamini, V., and Sears, L., (2015). The Unequal Benefits of Fuel Subsidies Revisited: Evidence for Developing Countries, IMF working paper WP/15/250, International Monetary Fund.

Dartanto, T. (2013). Reducing Fuel Subsidies and the Implication on Fiscal Balance and Poverty in Indonesia: A simulation Analysis, Energy Policy 58, pp. 117-134.

International Energy Agency (2015). https://www.iea.org/ countries/Oman.

Kotagama, H., Al Jabri, S., Boughanmi, H., and Guizani, N., (2014). Impact of Food Prices, Income and Income Distribution on Food Security in Oman. In Environmental Cost and Face of Agriculture in the Gulf Cooperation Council Countries, Shabbir A. Shahid and Mustaque Ahmed (Ed), Springer, pp. 145-162.

Kshirsagar, V., Simler, K. and Zaman, H. (2009). A Simulation Model for Estimating the Poverty Impact of Changes in Food and Fuel Prices, The World Bank, http://siteresources.worldbank.org/INTPOVERTY/Resources/F ood_Fuel_SimulationModel_UsersGuide.pdf.

Mbaga, M. and Kotagama, H. (2010). Food Demand Survey: Indicative Demographic Trends, A Consultancy Report Submitted to GRM International, 15 May 2010.

Ministry of National Economy (2010). The Important Result of Household Expenditure and Income Survey Results from 20/5/ 2007 to 19/5/2008. Ministry of National Economy (MNE), Directorate General of Social Statistics, Sultanate of Oman.

Ministry of Social Development (2015). Statistical Bulletin of Social Security, Sultanate of Oman.

National Centre for Statistics and Information (NCSI) (2012). The Final Findings of the Household Expenditure and Income Survey, Sultanate of Oman. 
PricewaterhouseCoopers International Limited (2016). Oman State Budget- Austerity Measures and Focus on Non-oil and Gas Revenue, Economic Developments in Oman from Tax and Legal Services Middle East, https://www.pwc.com/m1/en/tax/documents/2016/oman-2016budget-newsalert.pdf

Rentschler, J.E. (2015). Incidence and Impact: A Disaggregated Poverty Analysis of Fossil Fuel Subsidy Reform, OIES Working Paper: SP36, The Oxford Institute for Energy Studies, Oxford, UK.

Siddig, K., Aguiar, A., Grethe, H., Minor, P., and Walmsley, T. (2014). Impacts of Removing Fuel Import Subsidies in Nigeria on Poverty, Energy Policy, 69, pp. 165-178.

Simler, K. (2010). Assessing the Welfare Impacts of Food and Fuel Price Shocks, http://siteresources.worldbank.org/INTPOVERTY/Resources/ WelfareImpact_PriceShocks.pdf

World Bank (2016). Oman's Economic Outlook, https://www.worldbank.org/en/country/gcc/publication/omanseconomic-outlook-fall-2016. 